\title{
Correlation Analysis among 290 Inbred Lines of Maize (Zea mays L.)
}

\author{
K. Aruna*, E. Gangappa and Puttarama Naik \\ Department of Genetics and Plant Breeding, University of Agricultural and Horticultural \\ Sciences, Shivamogga-577225, Karnataka, India \\ *Corresponding author
}

\section{A B S T R A C T}

\begin{tabular}{|c|}
\hline Keywords \\
\hline $\begin{array}{l}\text { Grain production, } \\
\text { inbreds and hybrids } \\
\text { Grain yield plant }\end{array}$ \\
\hline Article Info \\
\hline $\begin{array}{l}\text { Accepted: } \\
12 \text { February } 2020 \\
\text { Available Online: } \\
10 \text { March } 2020\end{array}$ \\
\hline
\end{tabular}

Maize (Zea mays L.) is the third most important cereal in India after rice and wheat. It is grown in 178 million hectares globally in about 160 countries and contributes to $50 \%$ of global grain production (1,170 million MT). Area under maize is consistently, showing increasing trend as there is high demand for maize as it is used as input for large number of products. This demand needs to be met out from shrinking land resources and other production constraints. Yield is a complex inherited character and therefore, direct selection for yield per se may not be the most efficient method for its improvement. Indirect selection for other yield related characters with high correlation will be more effective. Correlation studies between yield and yield components are pre-requisite to plan a meaningful breeding programme to develop high yielding inbreds and hybrids. With this background, investigation was conducted to study the coefficient of correlation among 290 maize inbred lines. 290 inbred lines were raised in augmented design with 10 blocks including three checks in each block. Seeds were sown in a row length of $3 \mathrm{~m}$ with $0.6 \mathrm{~m}$ distance between rows and $0.3 \mathrm{~m}$ distance between plants. Analysis of variance revealed significant difference between the inbred lines indicating the presence of diversity among inbred lines. Grain yield plant ${ }^{-1}$, being the most important trait was found positively and highly correlated with kernels row $^{-1}(0.816)$, cob diameter $(0.813)$, cob length $(0.811)$ and 100 seed weight $(0.706)$. These traits exhibiting highly significant correlation suggests that, selection for these traits in a breeding program will help in enhancing the grain yield plant $^{-1}$ per se.

\section{Introduction}

Maize (Zea mays L.) is the third most important cereal in India after rice and wheat (Centre for Monitoring Indian Economy, 2017).It is cultivated from $58^{\circ} \mathrm{N}$ to $40^{\circ} \mathrm{S}$, from below sea to altitudes higher than $3000 \mathrm{~m}$; in areas with $250 \mathrm{~mm}$ to more than $5000 \mathrm{~mm}$ of rainfall (Downswell et al., 1995) indicating its wider adaptability. It is grown in 178 million hectares globally in about 160 countries and contributes to $50 \%$ of global grain production (1,170 million MT).

In India, maize constitutes $9 \%$ of the total volume of cereals produced with $23 \mathrm{~m}$ MT production and is the third most important food grain after rice $(42 \%)$ and wheat $(38 \%)$ with a productivity of $2.5 \mathrm{t} \mathrm{ha}^{-1}$ (Anon, 2015). Karnataka stands at $7^{\text {th }}$ position in India in 
maize production with an area of $1.18 \mathrm{~m}$ ha in 2015-16, producing $3.27 \mathrm{~m} \mathrm{t}$ with a productivity of $2773 \mathrm{~kg} \mathrm{ha}^{-1}$ (Anon, 2017). Maize provides food, feed, fodder, fuel and serve as a source of basic raw material for a number of industrial products viz., starch, oil, protein, alcoholic beverages, food sweeteners, cosmetics and bio-fuel etc.

Yield is a complex inherited character and therefore, direct selection for yield per se may not be the most efficient method for its improvement. Indirect selection for other yield related characters with high correlation will be more effective. Hence, correlation studies between yield and yield components are pre-requisite to plan a meaningful breeding programme to develop high yielding inbreds and hybrids.

\section{Materials and Methods}

Experiment was conducted at Zonal Agricultural Research Station, Mandyato study the correlation. 290 inbred lines including three checks viz., SKV-50, MAI105 and MAI-137 collected from CIMMYT, Zonal Agriculture Research Station, Mandya and University of Agricultural Sciences, Bengaluru constituted the experimental material for this experiment.

290 inbred lines were raised in augmented design with 10 blocks including three checks in each block. Seeds were sown in a row length of $3 \mathrm{~m}$ with $0.6 \mathrm{~m}$ distance between rows and $0.3 \mathrm{~m}$ distance between plants. All the recommended crop production and crop protection practices were followed to raise a healthy crop.

Nitrogen was applied in two split doses; $60 \mathrm{~kg}$ at the time of sowing and $60 \mathrm{~kg}$ at knee height stage followed by intercultural operations. Preventive and curative sprays were given as and when required to ensure pest and disease- free crop. Observations on yield attributing characters viz., days to $50 \%$ silking, days to $50 \%$ tasseling, anthesis-silking interval, plant height, cob length, cob diameter, kernel rows $\mathrm{cob}^{-1}$, kernerls row ${ }^{-1}$, grain yield plant ${ }^{-1}, 100$ seed weight and cob shelling per centwere recorded on five randomly selected plants of each inbred line based on counting/measurement using appropriate scale depending on the traits.

\section{Results and Discussion}

Analysis of variance revealed significant difference between the inbred lines indicating the presence of diversity among inbred lines (Table 1). Significant difference in analysis of variance suggests for further analyses to unravel the correlation among different characters.

Correlation study helps to reveal the direction and magnitude of relationship among the different traits. This facilitates in understanding the influence of one trait on the other. In any plant breeding program grain yield is given prime importance as it is the mandatory part of any improved cultivar. Hence, correlation of traits with the grain yield is more important that other combinations of correlation among traits.

In this study, grain yield plant ${ }^{-1}$ showed significant and positive correlation with all the traitsexcept days to silking (-0.328), days to tassel (-0.264) and anthesis-silking interval (-0.230) which showed significant and negative correlation with grain yield plant ${ }^{-}$ ${ }^{1}$ (Ojo et al., 2006; Nataraj et al., 2014; Ram Reddy et al., 2013).

Highly significant correlation with grain yield plant $^{-1}$ was observed for kernels row ${ }^{-1}(0.816)$, cob diameter (0.813), cob length (0.811) and 100 seed weight (0.706) (Wannows et al., 2010; Pavan et al., 2011; Kumar et al., 2006). 
Table.1 Analysis of Variance for 290 inbred lines for yield and its component traits

\begin{tabular}{|c|c|c|c|c|c|c|c|c|c|c|c|c|}
\hline $\begin{array}{l}\text { Source of } \\
\text { Variation }\end{array}$ & $\begin{array}{l}\text { Degrees } \\
\text { of } \\
\text { freedom }\end{array}$ & DAS & DAT & ASI & PH & CL & CD & KRC & KR & GYP & 100SW & $\mathrm{CS} \%$ \\
\hline $\begin{array}{l}\text { Block } \\
\text { (Ignoring } \\
\text { treatments) }\end{array}$ & 9 & $14.14 * * *$ & $9.97 * *$ & $2.83 * *$ & $2195.52 * * *$ & $14.2 * * *$ & 0.56 & $3.11 * * *$ & $88.87 * * *$ & $2098.87 * * *$ & $49.26 * * *$ & $59.92 * * *$ \\
\hline $\begin{array}{l}\text { Inbred } \\
\text { lines + } \\
\text { Checks } \\
\text { (Ignoring } \\
\text { blocks) }\end{array}$ & 292 & $18.41 * * *$ & $17.80 * * *$ & $2.66 * * *$ & $642.15^{* * *}$ & $6.61 * *$ & $2.39 *$ & $3.73 * * *$ & $43.69 * * *$ & $1802.89 * * *$ & $34.97 * * *$ & $33.83 * * *$ \\
\hline $\begin{array}{l}\text { Inbred } \\
\text { lines }\end{array}$ & 289 & $18.36 * * *$ & $17.24 * * *$ & $2.59 * * *$ & $641.17 * * *$ & $6.54 * *$ & 2.18 & $3.20 * * *$ & $41.20 * * *$ & $1734.72 * * *$ & $34.01 * * *$ & $33.35 * * *$ \\
\hline Checks & 2 & $25.43 * * *$ & $63.70 * * *$ & $6.70 * *$ & 343.63 & $10.46^{*}$ & $12.43 * * *$ & $74.36 * * *$ & $257.30 * * *$ & $7983.58 * * *$ & $39.69 *$ & $99.21 * * *$ \\
\hline $\begin{array}{l}\text { Checks vs. } \\
\text { Inbred line }\end{array}$ & 1 & $20.93 * *$ & $89.01 * * *$ & $16.68 * * *$ & $1522.66^{* *}$ & $21.80 * *$ & $41.62 * * *$ & $15.10 * * *$ & $336.39 * * *$ & $9143.02 * * *$ & $304.74 * * *$ & $44.01 *$ \\
\hline Error & 18 & 1.62 & 2.14 & 0.66 & 124.71 & 1.92 & 1.13 & 0.35 & 1.26 & 114.37 & 7.66 & 8.43 \\
\hline
\end{tabular}

DAS- days to silking; DAT - days to tassel; ASI - anthesis-silking interval; PH - plant height; CL - cob length; CD - cob diameter; KRC - kernel rows cob ${ }^{-1}$;

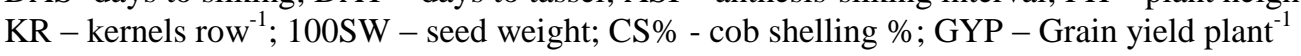


Table.2 Estimates of correlation co-efficient at phenotypic level

\begin{tabular}{|c|c|c|c|c|c|c|c|c|c|c|c|}
\hline & DAS & DAT & ASI & PH & $\mathbf{C L}$ & CD & KRC & $\mathbf{K R}$ & 100SW & $\mathrm{CS} \%$ & GYP \\
\hline DAS & 1 & $0.915 * * *$ & $0.258 * * *$ & -.0059 & $-265 * * *$ & - $0.247 * * *$ & -0.051 & $0.316 * * *$ & - $0.208 * * *$ & -0.065 & - $0.328 * * *$ \\
\hline DAT & & 1 & $-0.124 *$ & -0.001 & $\begin{array}{l}- \\
0.223 * * *\end{array}$ & $-0.184 * *$ & -0.021 & $\begin{array}{l}- \\
0.253 * * *\end{array}$ & $-0.142 *$ & -0.033 & $\begin{array}{l}- \\
0.264 * * *\end{array}$ \\
\hline ASI & & & 1 & - & $-0.168 * *$ & - $0.223 * * *$ & $-0.115^{*}$ & - $0.223 * * *$ & $-0.179 * *$ & -0.113 & $0.230 * * *$ \\
\hline PH & & & & 1 & $0.426 * * *$ & $0.382 * * *$ & $0.204 * * *$ & $0.394 * * *$ & $0.354 * * *$ & $0.170 * *$ & $0.452 * * *$ \\
\hline $\mathbf{C L}$ & & & & & 1 & $0.634 * * *$ & $0.227 * * *$ & $0.818 * * *$ & $0.579 * * *$ & $0.208 * * *$ & $0.811 * * *$ \\
\hline CD & & & & & & 1 & $0.532 * * *$ & $0.602 * * *$ & $0.654 * * *$ & $0.318 * * *$ & $0.813 * * *$ \\
\hline KRC & & & & & & & 1 & $0.234 * * *$ & 0.020 & $0.155 * *$ & $0.359 * * *$ \\
\hline KR & & & & & & & & 1 & $0.414 * * *$ & $0.397 * * *$ & $0.816 * * *$ \\
\hline 100SW & & & & & & & & & 1 & $0.294 * * *$ & $0.706 * * *$ \\
\hline $\mathrm{CS} \%$ & & & & & & & & & & 1 & $0.441 * * *$ \\
\hline
\end{tabular}

DAS- days to silking; DAT - days to tassel; ASI - anthesis-silking interval; PH - plant height; CL - cob length; CD - cob diameter; KRC - kernel rows cob ${ }^{-1}$; $\mathrm{KR}$ - kernels row ${ }^{-1} ; 100 \mathrm{SW}$ - seed weight; CS\% - cob shelling \%; GYP - Grain yield plant ${ }^{-1}$ 
These traits exhibiting highly significant correlation suggests that, selection for these traits in a breeding program will help in enhancing the grain yield plant ${ }^{-1}$ per se. Traits exhibiting significant and negative correlation suggests the negative selection for those traits (days to silking, days to tassel and anthesissilking interval) to improve the grain yield plant $^{-1}$.

The component traits studied for the set of 290 inbred lines of maize showed significant correlation with the grain yield plant ${ }^{-1}$ and among themselves indicating the presence of inter-relationship. Traits showing highly significant and significant correlation with the grain yield plant ${ }^{-1}$ can be used as surrogate trait in selection for high yield.

\section{References}

Anonymous, 2015.Annual progress report, Directorate of Maize Research. NewDelhi.

Anonymous, 2017.Annual progress report, Directorate of Maize Research. New Delhi.

Downswell, C. R., 1995. Single wheat kernel analysis by near-infrared transmittanceprotein content.Cereal Chem., 72: 1116.

Kumar, S., Shahi, J. P., Singh, J. and Singh, S. P., 2006.Correlation and path analysis in early generation inbreds of maize (Zea mays L.).Crop Improv.,2: 156-160.

Nataraj, V.,Shahi, J. P. andAgarwal, V., 2014.Correlation and path analysis in certain inbred genotypes of maize (Zea mays L.) at Varanasi.Int. J.Innov. Res. Sci. Eng. Technol., 14-17.

Ojo, D. K., Omikunle, O. A., Oduwoye, O. A., Ajala, M. O. andOgunbayo, S. A., 2006. Heritability, character correlation and path coefficient analysis among six inbred lines of maize. World J. Agric. Sci., 3: 352-358.

Pavan, R., Lohithaswa, H. C., Wali, M. C., GangashettyPrakash, Shekara, B. G., 2011.Correlation and path analysis of grain yield and yield contributing traits in single cross hybrids of maize (Zea mays L.). Electron J. Pl. Breed.,2: 253257.

Ram Reddy, V.,Farzana, J. S. M. R. andSeshagiriRao, A., 2013.Studies on genetic variability, heritability, correlation and path analysis in maize (Zea mays L.)Over locations.Int. J. Appl. Bio. Pharma. Tech.,1: 195-199.

Wannows, A. A., Azzam, H. K. and AlAhmad, S. A.,2010, Genetic variances, heritability, correlation and path coefficient analysis in yellow maize crosses (Zea mays L.).Agr. Biol. J. N. Am.,1: 630-637.

\section{How to cite this article:}

Aruna. K, E. Gangappa and Puttarama Naik. 2020. Correlation Analysis among 290 Inbred Lines of Maize (Zea Mays L.). Int.J.Curr.Microbiol.App.Sci. 9(03): 1419-1423. doi: https://doi.org/10.20546/ijcmas.2020.903.165 